\title{
The Waning Grand Strategy of Democratization: Why a Pivot to the Asia-Pacific Places the United States at Greater Risk of Terrorist Attack
}

\author{
David Tier *
}

Our world is on a trajectory leading to a point where terrorists will eventually acquire a nuclear weapon. ${ }^{1}$ It is only a matter of time. ${ }^{2}$ After the terrorist attacks of September 11 , 2001, the United States recognized the lack of effectiveness of its previous intelligence and military efforts in deterring terrorists and sought an alternate way to defuse the radical Islamist threat. ${ }^{3}$ By continuing to advocate the use of military force in Iraq after weapons of mass destruction were not found, the U.S. pursued a strategy in line with the idealist school of thought by attempting to plant a democracy in the heart of the Middle East. ${ }^{4}$ Iraq became the centerpiece of the United States' ambitions to stop the region from exporting violence and terror, and attempted to transform it into a place of progress and peace. ${ }^{5}$ This effort was ambitious indeed, and many argued that these goals were beyond the United States' ability to achieve. However, this strategy offered a possible solution to the endless cycle of violence across the Middle East and Africa and its continuing threat to U.S. national security. The current administration, in contrast, announced last year a "rebalance toward the Asia-Pacific region," ostensibly to counter the growing strength of China's military power. ${ }^{6}$ Like an ostrich sticking its head in the sand, this shift pivots the U.S. away from its true threat and increases the peril its citizens will face. The United States should focus its efforts on supporting democratization in troubled regions, and policy makers must counter those who criticize this strategy, including military-industrial complex advocates of the "pivot."

\footnotetext{
David Tier is a Major in the U.S. Army and serves as a strategic plans and policy officer. He holds a Master in Public Administration degree from the Kennedy School of Government at Harvard University. He has completed three tours of duty in Iraq, having served as a cavalry troop commander as well as in various staff officer positions. He has also served a tour of duty in the Pentagon. The views presented here are those of the author do not necessarily represent the views of the U.S. Department of Defense or its components.

1 Attributed to Warren Buffett in Graham Allison, Nuclear Terrorism: The Ultimate Preventable Catastrophe (New York: Henry Holt and Company, 2005), 14.

Ibid.

3 Executive Office of the President, The National Security Strategy of the United States of America (Washington, D.C.: The White House, September 2002), v.

4 George W. Bush, President's Address to the Nation, "Update in the War on Terror," 7 September 2003; available at http://www.presidentialrhetoric.com/speeches/09.07.03.html.

5 Ibid.

6 U.S. Department of Defense, "Sustaining U.S. Global Leadership: Priorities for $21^{\text {st }}$ Century Defense" (Washington, D.C.: Department of Defense, January 2012), 2; available at http://www.defense.gov/news/defense_strategic_guidance.pdf.
} 


\section{Is China the Real Threat?}

Several of China's antagonistic actions have come to the forefront of news in recent years. China's vigorous assertion of territorial claims in the East China Sea, increasing development of its military capability, malicious cyber activity, humanitarian concerns, and continued difficulty in acting as a free-market trading partner have garnered the world's attention. But how has the present U.S. administration come to regard emerging security concerns in the Asia-Pacific as more serious than those on which the previous administration focused?

The answer is that elements of the U.S. military-industrial complex are seeking a new Cold War-like confrontation to sustain the spending levels to which they have grown accustomed over the past sixty years. ${ }^{7}$ Defense industries want to sell high-priced weapons, and the armed services want large budgets to command. ${ }^{8}$ These actors-who stand to profit most from a new Cold War-hope to convince the U.S. that China is its most serious threat. ${ }^{9}$ The prospect of low-intensity brushfire wars characteristic of the nation-building and counterinsurgency conflicts of the Global War on Terrorism are not the most profitable for all parties involved. ${ }^{10}$ With a sophisticated technological threat that poses challenges along the lines that their advanced weapons programs are designed to meet, China has become the adversary of choice of the U.S.-based military-industrial complex. $^{11}$

Despite efforts to paint China as an aggressive nation seeking to forcefully expand its sphere of influence, China will not pose an existential threat to the United States like the Soviet Union did years ago. ${ }^{12}$ Although China will likely continue to engage in a host of activities that will affect interests in the South China Sea, they do not share the same ideology or global ambitions the Soviet Union held during the Cold War. ${ }^{13}$ They are not seeking to spread communism around the world through subversion or overt force. ${ }^{14}$ China's interests may compete with some U.S. interests in East Asia, but the U.S. has no vital interest in the region that is seriously threatened. ${ }^{15}$ Maritime trade routes that could

7 Thomas P.M. Barnett, “AirSea Battle: The Military-Industrial Complex's Self-Serving Fantasy," Time (8 August 2012); available at http://nation.time.com/2012/08/08/airsea-battle-themilitary-industrial-complexs-self-serving-fantasy/.

Ibid.

9 Robert Kelly, "Why the West Should Relax About China," The Diplomat (6 September 2013); available at http://thediplomat.com/2013/09/06/why-the-west-should-relax-about-china. Ibid.

11 Barnett, “AirSea Battle: The Military-Industrial Complex's Self-Serving Fantasy.”

12 Joseph S. Nye, Jr., reply to writer in "The China Threat," Foreign Policy (March/April 2011); available online at http://www.foreignpolicy.com/articles/2011/02/22/the_china_threat.

13 Hugh White, The China Choice: Why We Should Share Power (Oxford: Oxford University Press, 2013), 54.

14 Nye, "The China Threat"; White, The China Choice.

15 Marvin C. Ott, "The Imperative for an American Strategy for Southeast Asia" (Foreign Policy Research Institute, September 2013); available at www.fpri.org/articles/2013/09/imperativeamerican-strategy-southeast-asia. 
be affected have alternate courses. ${ }^{16}$ Changes in Asian economic affairs may have an impact on U.S. wallets, but downturns would unlikely threaten the United States' livelihood, let alone its survival. ${ }^{17}$ In fact, many of the United States' interests that involve China are complementary rather than competitive. ${ }^{18}$ China's primary focus is increasing its trade and commerce. ${ }^{19}$ They are promulgating capitalist practices, albeit without regard to copyright infringement and with a decidedly government-interventionist slant, rather than seeking to supplant the global market system like the Soviets did. ${ }^{20}$

Unlike the fundamentally opposed interests between the former Cold War blocs, China's potential conflicts with the U.S. do not threaten each other's existence. They do not have the world teetering at the brink of nuclear war between superpowers holding competing ideologies. Most of China's potential conflicts are localized territorial disputes with its neighbors. ${ }^{21}$ Disputes with Taiwan may have existential implications for the two regimes directly concerned, but this dispute does not threaten vital U.S. national interests. ${ }^{22}$ Chinese developments such as the "carrier-killing" DF-21, anti-satellite technologies, and cyber capabilities are intended to support operations in these types of conflicts, not blue-water warfare on the high seas. ${ }^{23}$ Accordingly, future Chinese military efforts will focus on readiness for potential regional conflicts close to their borders as well as protecting commercial lines of communication. ${ }^{24}$ China's efforts to protect regional sea lanes will actually complement U.S. security efforts since the U.S. and China share trade routes. ${ }^{25}$ One example of these shared maritime security interests between the two

16 John H. Noer with David Gregory, "Maritime Economic Interests \& the Sea Lines of Communication through the South China Sea: The Value of Trade in Southeast Asia," U.S. Center for Naval Analyses (March 1996), 8; available at http://www.cna.org/research/1996/ maritime-economic-interests-sea-lines.

17 Craig K. Elwell, Marc Labonte, and Wayne M. Morrison, Is China a Threat to the U.S. Economy? (Washington, D.C.: Congressional Research Service, 23 January 2007), 3-4.

19 Ibid.

19 Ibid.

20 John Yemma, "The China Paradox: Communist Capitalism?" The Christian Science Monitor (4 November 2011); available at http://www.csmonitor.com/Commentary/editors-blog/2011/ 1104/The-China-paradox-communist-capitalism.

21 Ian Storey, "Asia's Changing Balance of Military Power: Implications for the South China Sea Dispute," in Maritime Energy Resources in Asia: Energy and Geopolitics, ed. Clive Schofield (Seattle, WA: National Bureau of Asian Research, December 2011), notes 11-12.

22 The Commission on America's National Interests, led by Robert Ellsworth, Andrew Goodpaster, Rita Hauser, Graham Allison, Dimitri Simes, and James Thompson, "America's National Interests" (Cambridge, MA: Belfer Center for Science and International Affairs, July 2000), 5; available online at http://belfercenter.hks.harvard.edu/files/amernatinter.doc.

23 Ronald O'Rourke, China Naval Modernization: Implications for U.S. Navy Capabilities Background and Issues for Congress (Washington, D.C.: Congressional Research Service, 5 September 2013), ii.

24 Storey, "Asia's Changing Balance of Military Power: Implications for the South China Sea Dispute," notes 12-20.

25 U.S. Center for Naval Analyses, "Maritime Economic Interests \& the Sea Lines of Communication Through the South China Sea," 13. 
nations is in the troubled waters near the Horn of Africa, where both countries could cooperate for mutual benefit to reduce the threat of piracy. Some have suggested that China has purchased significant amounts of U.S. debt to hold as a potential weapon against the U.S. ${ }^{26}$ As an investor, it is actually in China's interest to protect U.S. creditworthiness rather than engage in activity that could destabilize the U.S. economy. ${ }^{27}$

China has little to gain in seeking a major conflict with the U.S. far from their homeland, nor do they have much prospect of increasing their potential reward if they were to win such a conflict. ${ }^{28}$ With little hope of breaking U.S. dominance of the sea, ${ }^{29}$ the primary consequence of a Chinese victory in some far-flung engagement would be to subject itself to the will of Washington's desires in the maritime domain. Granted, the possibility for Chinese military aggression is stronger in regional territorial disputes, as is evidenced by their aggressive behavior toward their near neighbors. However, China's regional aggression can be foiled by strengthening regional alliances and encouraging the military modernization of threatened countries. ${ }^{30}$

The most worrisome aspect of the focus on China is that exaggerating the potential threat could turn into a self-fulfilling prophecy. ${ }^{31}$ Increased U.S. military deployments in the Asia-Pacific could heighten tensions and trigger escalation leading to accidental conflict, even when peaceful resolutions of these territorial disputes are within reach. ${ }^{32}$ Developments between China and Taiwan show greater prospects for a diplomatic resolution than in the past. ${ }^{33}$ China is a regional power whose military interests are regional. ${ }^{34}$ The threat of Islamist terrorists, however, remains a very real global threat to U.S. interests.

Associates of A.Q. Khan, the Pakistani scientist known for assisting nuclear proliferation in North Korea and Iran, allegedly met Osama Bin Laden before September

26 Wayne M. Morrison and Marc Labonte, China's Holdings of U.S. Securities: Implications for the U.S. Economy (Washington, D.C.: Congressional Research Service, 19 August 2013), ii. Ibid.

28 Robert Kaplan, "The South China Sea Is the Future of Conflict," Foreign Policy (September/October 2011); available at http://www.foreignpolicy.com/articles/2011/08/15/the south_china_sea_is_the_future_of_conflict?page $=0,4$.

Sydney J. Freedberg, Jr., "China's Fear of US May Tempt Them To Preempt: Sinologists," Breaking Defense (1 October 2013); available at http://breakingdefense.com/2013/10/chinasfear-of-us-may-tempt-them-to-preempt-sinologists/.

30 Kelly, "Why the West Should Relax About China."

31 Freedberg, "China's Fear of US May Tempt Them To Preempt: Sinologists."

32 Matthew Hipple, "99 Red Balloons: How War With China Would Start," War on the Rocks (13 November 2013); available at http://warontherocks.com/2013/11/how-war-with-chinawould-start-99-red-balloons/.

33 Kent Wang, "A Peace Agreement Between China and Taiwan," The Diplomat (5 September 2013); available at http://thediplomat.com/china-power/a-peace-agreement-between-chinaand-taiwan/.

34 Storey, "Asia's Changing Balance of Military Power: Implications for the South China Sea Dispute," note 12. 
2001 in an attempt to sell nuclear weapons technology. ${ }^{35}$ Bin Laden is said to have declined the offer in favor of more near-term plans. ${ }^{36}$ Nonetheless, the possibility of a nuclear-armed Al Qaeda — or any other hostile terrorist organization, for that matter-persists as the United States' greatest security threat. ${ }^{37}$ After repeated attacks against the U.S. and its interests abroad, who can doubt Al Qaeda's aspiration to inflict the greatest possible harm on the U.S. within their means? ${ }^{38}$ This is the threat the United States should be focused on reducing.

\section{Countering the Bomb}

To lessen this threat, the United States must recognize what presently keeps it safe. Since the ungoverned spaces of unstable countries offer ideal sites for terrorists to organize attacks, the only obstacle preventing a terrorist nuclear attack against the United States is the terrorists' lack of capability. ${ }^{39}$ Terrorist groups lack the necessary combination of technical material, expertise, and tactical skill. Unfortunately, the tactical skill required to deliver a nuclear device to the United States is not difficult to attain. ${ }^{40} \mathrm{Be}-$ tween porous borders, colossal volumes of shipping containers arriving at U.S. ports, and a number of successful attacks on U.S. soil that demonstrate some amount of terrorist capability, the United States must assume that if a terrorist organization were to gain possession of an improvised nuclear device it would be able to smuggle such a weapon to a target within the nation's borders. ${ }^{41}$ Therefore, only the lack of material and expertise is what presently keeps the U.S. safe from terrorist attack with a weapon of mass destruction. ${ }^{42}$ It stands to reason that the United States should focus most of its efforts on preventing these organizations from gaining access to such weapons. Yet, the policy of the United States is to pivot towards conventional threats in the Asia-Pacific. This incorrectly prioritizes the threats the U.S. faces, and promises to misallocate the nation's scarce security resources.

Unfortunately, even efforts to deny terrorist groups the material and expertise necessary to acquire a nuclear weapon or other weapon of mass destruction will eventually be a losing proposition. Given determination, financial resources, and with unlimited time, one of these groups will eventually be able to gather the components necessary to obtain

35 Douglas Frantz and Catherine Collins, The Nuclear Jihadist: The True Story of the Man Who Sold the World's Most Dangerous Secrets and How We Could Have Stopped Him (New York: Twelve Hachette Group, 2007), 365.

36 Ibid.

37 Joseph S. Nye, Jr., The Future of Power (New York: Public Affairs, 2011), 232.

38 Stephen M. Walt, "Beyond Bin Laden," International Security 26:3 (Winter 2001/2002): 67.

39 For a more detailed study of the required capabilities, see: James W. Moore, "Nuclear Terrorism: Exaggerating the Threat?" The Journal of Conflict Studies 26:1 (2006): 121-142; available at http://journals.hil.unb.ca/index.php/jcs/article/view/2172/2572.

40 Allison, Nuclear Terrorism, 10-11.

41 Ibid.

42 Ibid. 
or produce a weapon. ${ }^{43}$ The fact that unstable nations such as Pakistan and Syria already possess weapons of mass destruction gives cause for worry. ${ }^{44}$ It does not require a wild imagination to envisage some unfortunate combination of events that could result in a weapon falling into the wrong hands. Furthermore, as dramatized in entertainment media, there are plausible scenarios whereby terrorists could recruit personnel that could develop such weapons on their own. ${ }^{45}$ The only question that remains is how long the U.S. can frustrate their attempts or otherwise interdict efforts of terrorist groups to obtain a weapon of mass destruction. The United States' effort to buy time yields an important opportunity, however: the opportunity to change the situation.

\section{Problems and Solutions}

The problem with the situation as it presently stands is that regional culture in the Middle East sustains a level of hostility towards the United States unmatched anywhere else. ${ }^{46}$ This enmity promises to motivate future attempts at inflicting the greatest damage possible against U.S. society. ${ }^{47}$ In order to change this in a manner consistent with the United States' values, the U.S. must transform either its enemies, or itself, so that the hatred abates and the two sides can peacefully coexist. There are too many that hate the United States, they are too difficult to find, they are spread too far apart, and the seeds of future hatred are woven too deeply within their societies for the U.S. to be able to destroy or suppress them with bombing from afar. With the stakes too high to allow even one successful WMD attack, and the very small chance of destroying the threat through the use of force alone, the only solution that stands a chance of allowing the U.S. to rest peacefully is one that changes dynamics in the Middle East. To put this idea another way, Abraham Lincoln once said, "Do I not destroy my enemies when I make them my friends?" 48 This is the path the U.S. must follow if it wants to secure itself while remaining true to its values. The United States may not be able to forcefully impose a solution upon the many that want to harm it, but it must change the trajectory the world is currently on. To reconcile Middle Eastern enmity against it, the United States must recognize what causes their hatred and examine which options offer the best hope in ameliorating the issues.

Middle Eastern hostility towards the United States is caused by U.S. support for Israel as a sovereign nation, belligerent interpretation of some Islamic religious principles, and the existence of oppressive regimes that prohibit political opposition or deny freedom of expression. ${ }^{49}$ There should be little disagreement that these phenomena exist in

\footnotetext{
Ibid.

Ibid.

Ibid.

46 Walt, "Taming American Power," Foreign Affairs (September/October 2005); and Abdel Mahdi Abdallah, "Causes of Anti-Americanism in the Arab World: A Socio-Political Perspective," Middle East Review of International Affairs 7:4 (December 2003): 63.

47 Walt, "Beyond Bin Laden," 67.

48 Robert Greene and Jost Elfers, The 48 Laws of Power (London: Profile Books, 2000), 12.

49 Abdallah, "Causes of Anti-Americanism in the Arab World," 62.
} 
the Greater Middle East. The only question should be whether or not these causes constitute a complete list and to what degree each of them serves as a source of hostility. To correctly characterize a problem is half the difficulty of finding its solution, but in the interest of finding answers to these well-known existing problems, let us examine how the U.S. could ameliorate each of them.

There appears to be little hope of soothing Arabs over the United States' support of Israel. Nor should the U.S. backpedal from the Israelis. ${ }^{50}$ Although "kicking the can down the road" with temporary peace deals has been the preferred solution in the past, ${ }^{51}$ continuing this strategy will maintain the region's unacceptable trajectory. The depth of this problem is profound. Palestinians are indoctrinated as children to hate Israel and the U.S. ${ }^{52}$ A solution to fix this will take decades or generations. The United States shares responsibility for creating the state of Israel in the Middle East, ${ }^{53}$ and it should not deny that Israel has acted reasonably to defend itself from the many and varying threats they have historically faced. ${ }^{54}$ Despite efforts to paint Israel as an oppressive occupier, the behavior of parties claiming to be aggrieved is too appalling to sympathize with. Indiscriminate rocket attacks against population centers, suicide bombings against civilian targets, and rhetoric advocating extermination are not acceptable behaviors for parties to a negotiation. ${ }^{55}$ Where is the Mahatma Gandhi or Nelson Mandela of the Palestinian cause? Perhaps if Palestinians tried a different approach they would garner more international support. Until that time, for the U.S. to withhold support from Israel would be a concession to terrorism based on fear rather than on moral grounds.

A second cause of Middle Eastern hatred towards the U.S. has to do with the issue of a Muslim's duty to defend Islam. ${ }^{56}$ There are varying interpretations over the true meaning of certain passages in the Quran, but many followers believe that it is their duty to

50 Khaled Abu Toameh, "Palestinians: We Hate You, So Please Pay Us More," Gatestone Institute (22 March 2013); available at http://www.gatestoneinstitute.org/3637/palestinians-hateus.

51 J. Martin Rochester, "U.S. Foreign Policy: Kicking the Can Down the Road," St. Louis Jewish Light (18 September 2013); available at http://www.stljewishlight.com/opinion/ commentaries/article 0acf79ac-2091-11e3-a9be-0019bb2963f4.html.

52 Ibid; and Diane Miller, quote taken from Mark Oliver, "Palestinian TV uses Mickey Mouse to Promote Resistance," The Guardian (9 May 2007); available at http://www.theguardian.com/ world/2007/may/09/usa.israel.

53 The United States supported United Nations Resolution 181, calling for the partition of Palestine, and immediately recognized Israel as a sovereign nation upon its independence. U.S. Department of State Office of the Historian, "Creation of Israel, 1948"; available at http://history.state.gov/milestones/1945-1952/creation-israel.

54 See Yaacov Lozowick, Right to Exist: A Moral Defense of Israel's Wars (New York: Random House, 2003).

55 Nonie Darwish, "Why Muslims Must Hate Jews," The American Thinker (3 August 2012); available at http://www.americanthinker.com/2012/08/why_muslims_must_hate_jews.html.

56 Samuel Huntington, The Clash of Civilizations and the Remaking of the World Order (New York: Simon and Schuster, 1997), 209 and 217; Abdallah, "Causes of Anti-Americanism," 67. 
fight against those who attack Islam. ${ }^{57}$ Unfortunately, to some Muslims, the U.S. is seen as an opposing force because American principles advocate the freedom to choose one's own religious beliefs. ${ }^{58}$ This principle serves as a persuasive alternative in contrast with those who seek to enforce Sharia law on non-believers. ${ }^{59}$ With the spread of liberal Western principles transmitted through popular media across the world, the U.S. is seen as a source of cultural attack. ${ }^{60}$ There is no peaceful way to resolve discord like this where a one side's core values are pitted against those of the other side. The hard truth of the matter is that, to resolve this cause of hatred, one party must forgo a value that they firmly believe in. The game must change.

The final cause of Middle Eastern hatred toward the U.S. is the existence of oppressive regimes that prohibit political opposition and deny freedom of expression. Through organized intimidation, threats of cruel punishment, and the lack of faith in legal systems, the populations of these countries live in a kind of pressure cooker where an individual's desire to choose his own life course is frustrated. ${ }^{61}$ With no outlet for this everbuilding anger, the pressure cooker eventually explodes and results in violence. ${ }^{62}$ Some nations, such as Iran, attempt to divert domestic hostility against the domestic regime and channel it towards the U.S. as a target, exacerbating the terrorist threat to the United States. ${ }^{63}$ As with the first two causes, a fundamental change to this system is needed in order to resolve conflict.

The previous administration proposed a path that offered to temper, if not eliminate, each of these causes of hatred. The idea was that democratic governments that guaranteed certain personal liberties could serve as a moderating force against violent extremism. ${ }^{64}$ Instead of passionate peoples being forced to remain silent under the threat of torture and death, the people would be able to speak their opinions freely without fear of

57 Sam Harris, "Who Are the Moderate Muslims?" The Huffington Post (16 February 2006); available at www.huffingtonpost.com/sam-harris/who-are-the-moderate-musl_b_15841.html.

58 For an examination of the compelled practice of Islam, see "Archi Medes," "Is There Compulsion in Islam?" available online at http://www.patheos.com/blogs/daylightatheism/ essays/is-there-compulsion-in-islam/.

59 See Andrew C. McCarthy, "Re: American Conservatives, Islam, and Religious Realism in U.S. Foreign Policy," The National Review (10 July 2013); available at www.nationalreview.com/corner/353076/re-american-conservatives-islam-and-religiousrealism-us-foreign-policy-andrew-c.

60 See quotes attributed to Al Qaeda spokesperson Suleiman Abu Gheith in Allison, Nuclear Terrorism: The Ultimate Preventable Catastrophe, 12-13.

61 Martha Crenshaw, "The Causes of Terrorism," Comparative Politics 13:4 (July 1981): 38384; and Quan Li, "Does Democracy Promote or Reduce Transnational Terrorist Incidents?" Journal of Conflict Resolution (2005): 280-81, 290-91, 294; available at http://www.uk.sagepub.com/martin3study/articles/Li.pdf.

62 Ibid.

63 Abdallah, "Causes of Anti-Americanism in the Arab World," 69.

64 President George W. Bush, "Freedom and Democracy in the Middle East," Address at the $20^{\text {th }}$ Anniversary of the National Endowment for Democracy, Washington, D.C. (6 November 2003). 
punishment, and vent their emotions in a more peaceful manner. ${ }^{65}$ Simply being able to let off steam, this approach held, would go a long way in reducing the potential for violence in the Greater Middle East. ${ }^{66}$ More so, the maturity and discipline citizens would learn while beginning to exercise their new liberties would result in a greater understanding of different perspectives, greater tolerance towards opposing points of view, and more willingness to compromise. Starting with the individual and then working its way upward to an entire society, the concept of democratization could change the game as we know it. ${ }^{67}$ The domino theory could work in the United States' favor, whereby people in neighboring countries could seek the same freedoms that their neighbors found as they learned of them. ${ }^{68}$ With the spread of understanding, tolerance, and compromise, perhaps Arabs could come to grips with the existence of the state of Israel and learn to peacefully coexist. Perhaps more moderate teachers of Islam would persuade their followers that the freedom to choose one's own religious beliefs improves their followers' understanding by reducing the number who follow blindly. This could persuade extremist followers of Islam that the West does not pose a cultural threat to Islamic values. Perhaps different perspectives would challenge the concept that identifies the U.S. as a source of evil, and people would exercise more healthy skepticism of their leaders' true intentions. The sum of these outcomes would be to stabilize the Greater Middle East. ${ }^{69}$ A grand strategy of democratization offers an opportunity to change the game.

\section{Democratization and its Critics}

The most cogent argument in favor of democratization as a U.S. grand strategy was advocated by the columnist Charles Krauthammer, who dubbed his view "democratic realism." ${ }^{70}$ Democratic realism, Krauthammer argued, would not seek to intervene everywhere to institute democracies, but rather to encourage democracy everywhere and only intervene when vital U.S. national interests were at stake. ${ }^{71}$ Although perhaps more of an idealist or liberal notion rather than realist, this would be a more pragmatic and betterdeveloped approach than that which was applied as initially conceived in the Bush Doctrine. More disciplined and economical, it remains consistent with American values, national identity, and stands as the best available option to ensure its security.

Critics that contest democratization as a grand strategy, however, point to the United States' difficulties in Iraq in an attempt to show that the strategy is fatally flawed. These critics tend to follow the realist school of thought, which contends that political actors

\footnotetext{
65 Walt, "Beyond Bin Laden," 72.

66 Ibid.

67 Peter T. Leeson and Andrea M. Dean, "The Democratic Domino Theory: An Empirical Investigation," American Journal of Political Science 53:3 (July 2009): 533-551; available at http://ssrn.com/abstract=1002262.

68 Bush, Address at the $20^{\text {th }}$ Anniversary of the National Endowment for Democracy.

69 Ibid.

70 Charles Krauthammer, "In Defense of Democratic Realism," The National Interest (Fall 2004): 15 .

71 Ibid., 17.
} 
are rational and exercise power only in their self-serving interests. They express reservations that spreading democracy is too risky, too costly, and could even backfire. ${ }^{72}$ What if - as happened in Palestine and in Nazi Germany, they contend-forces hostile to the U.S. come to power through democratic processes? ${ }^{73}$ Not only would the United States have undermined a government that could have kept an unfriendly population in check, but it also would then have legitimized a new enemy. The U.S. is better off with friendly dictatorial governments, realists say, even if they use objectionable methods to control their populations, than it is with hostile democracies. ${ }^{74}$ They argue it is unlikely that such efforts would help establish a democratic government friendly to the U.S. and, instead, would likely expend resources that would eventually yield little to show for the efforts, or actually worsen the situation for the U.S. ${ }^{75}$

Critics subscribing to this theory propose continuing Machiavellian-style politics similar to the approach practiced during the Cold War when both poles attempted to control Middle Eastern governments like a behind-the-scenes puppet master pulling strings. ${ }^{76}$ Following this model, the U.S. should strengthen or overthrow regimes according to its interests, without considering the regime's domestic behavior. ${ }^{77}$ However, not only did this prove to be an imperfect way of managing Cold War affairs (as was borne out by the end results in Iran, Iraq, and Afghanistan), but U.S. society has also come to view these actions as often leading to behavior inconsistent with its values. ${ }^{78}$ Although successful to some extent in its geopolitical strategy against the Soviets, this strategy backfired in other ways detrimental to U.S. national security. Iran's 1979 revolution turned an ally into a bitter enemy. Saddam Hussein's aggressive behavior led the U.S. to directly confront Iraq in the Gulf War. Afghanistan, while draining Soviet military resources, grew as a terrorist safe haven to harbor the United States' most deadly attackers. Supporting repressive regimes has backfired against the U.S. by increasing Middle Eastern enmity against it. ${ }^{79}$ If the United States continues to play realist power politics, it will fail to reduce enmity in the Middle East. U.S. leaders will also find it increasingly

72 Walt, "Top 10 Lessons of the Iraq War," Foreign Policy (20 March 2012); available at www.foreignpolicy.com/articles/2012/03/20/top_ten_lessons_of_the_iraq_war?page $=0,9$.

Daniel Pipes, "Democracy's Bitter Fruit," National Post (27 January 2006). Also attributed to U.S. State Department Bureau of Intelligence and Research by Patrick Basham and Christopher A. Preble, "The Trouble with Democracy in the Middle East," CATO Institute (30 November 2003); available at http://www.cato.org/publications/commentary/trouble-democracymiddle-east.

74 Daniele Archibugi, “Cosmopolitan Democracy and its Critics: A Review," European Journal of International Relations 10 (2004): 455.

75 Francis Fukuyama, "The Neoconservative Moment," The National Interest (Summer 2004).

76 Walt, "The Shattered Kristol Ball," The National Interest (1 September 2008); and Andrew J. Bacevich, "The Realist Persuasion," The Boston Globe (6 November 2005).

77 James Garrison, America as Empire: Global Leader or Rogue Power? (San Francisco: Berrett-Koehler, 2003), 96.

78 David Skidmore, Contested Social Orders and International Politics (Nashville, TN: Vanderbilt University Press, 1997), 210.

79 Abdallah, "Causes of Anti-Americanism in the Arab World," 68-70. 
difficult to maintain domestic support for such policies. ${ }^{80}$ Indeed, the United States should prioritize its values over its security, because if it were to sacrifice its values, what then would it become?

The realist criticism is wrong. Maintaining the same old strategy in the Middle East would eventually result in a non-state terrorist organization obtaining a weapon of mass destruction. ${ }^{81}$ If this is a threat that the U.S. can accept, then the realist criticism is valid. However, with a powerful weapon and the will to use it, this threat could spell doom for the United States. The U.S. should reject a view that would accept the eventual destruction of one of its cities and the corresponding death toll in tens of thousands when there is reasonable hope of preventing it. ${ }^{82}$ The nation can act within its means to deny this eventuality. ${ }^{83}$ Despite those who are quick to say that the endeavor in Iraq has failed after terrorist attacks are publicized, no result yet seen has proven that democratization does not work. ${ }^{84}$ The fact remains that Iraq is a sovereign nation with democratically elected representatives governing its peoples. This is success. ${ }^{85}$ Indeed, lending credence to a domino theory of democracy, the Arab Spring of 2011 may have been inspired by Iraq's progress, ${ }^{86}$ and these stories may encourage stronger movements in the future. ${ }^{87}$

Another mistake realist critics make is that they fail to account for the fact that, if an adversarial regime came to power through democratic processes, a previously veiled threat would then become fully revealed. The U.S. would no longer have to search in the shadows for that particular adversary. The threat would readily present itself in the form of a nation-state, and this nation-state would be much more susceptible to deterrence. Since a nation-state possesses a distinct and exclusive geographic region of responsibility, a seat of government, and a permanent population, it is vulnerable to military counterattack. ${ }^{88}$ The United States has decades-long experience practicing deterrence against state actors and, coupled with a credible ability to determine the perpetrator of an attack, nation-state enemies stand to lose a great deal by attacking U.S. interests. In a time when the risk of solitary WMD attacks exceeds the threat of conventional warfare in both likelihood and potential damage to vital interests, ${ }^{89}$ it is better for the U.S. to have an en-

80 Skidmore, Contested Social Orders and International Politics, 210.

81 Allison, Nuclear Terrorism, 14.

82 Ibid., 15.

83 Ibid.

84 Walt, "Top 10 Lessons of the Iraq War."

85 Max Boot, “A Hard-Won Account of a Hard-Won Victory," The Wall Street Journal (28 September 2012); and "Bartle B. Bull," "Victory in Iraq," The Weekly Standard 18:21 (11 February 2013). Both of these articles are summaries of Michael R. Gordon and Bernard E. Trainor, The Endgame (New York: Pantheon, 2012).

86 Shuvaloy Majumdar, "The Iraq War and the Arab Spring," Global Brief (27 June 2011); available at http://globalbrief.ca/blog/2011/06/27/the-iraq-war-as-cause-of-the-arab-spring/.

87 Alfred Stepan and Juan J. Linz, "Democratization Theory and the Arab Spring," Journal of Democracy 24:2 (April 2013): 29.

88 Stone, "Deterring Nonstate Actors," 269.

89 Ibid. 
emy revealed rather than being able to lurk quietly in the shadows of a repressive regime, or in the safe haven of ungoverned spaces.

Despite the announced "pivot" to the Asia-Pacific, the actions of the present administration are so far at least a reasonably good continuation of the previous policy, and perhaps even represent a small improvement. ${ }^{90}$ The United States appeared to follow a "democratic realist" democratization strategy during the Arab Spring. ${ }^{91}$ By intervening diplomatically during the regime change in Egypt, providing military support during operations against Libya, and initiating covert support of certain Syrian rebels, Washington has pursued a targeted, opportunistic, yet restrained, strategy of democratization in the Greater Middle East. ${ }^{92}$ Whether this policy was deliberately preconceived or applied in an ad hoc manner is another issue, but the resulting actions have been both significant and appropriate. ${ }^{93}$ However, words have meaning too. When official policy states that the United States will realign its strategy, resources, and military operational concepts towards the Asia-Pacific, it causes its planners and analysts to shift their focus towards the new region ${ }^{94}$ when they should remain focused on the Greater Middle East. ${ }^{95}$ The Asia-Pacific is important, to be sure, but the region should decidedly be of no higher than second priority in the United States' foreign and defense policy. As operations in Libya, crises in Syria, and the potential for non-combatant evacuation operations persisting throughout the region attest, the Greater Middle East is where the U.S. should continue to devote the greater proportion of its collective brainpower. ${ }^{96}$

90 Dave Boyer, "Bush Policies Still Alive in Obama White House," The Washington Times (24 April 2013); available at http://www.washingtontimes.com/news/2013/apr/24/bush-policiesstill-alive-in-obama-white-house/?page=all. See also Peter Feaver, "Obama's Embrace of the Bush Doctrine and the Meaning of 'Imminence'," Foreign Policy (5 February 2013); available at http://shadow.foreignpolicy.com/posts/2013/02/05/obamas_embrace_of_the_bush_ doctrine_and_the_meaning_of_imminence.

91 Dave Seminara, "Obama: Defender of Democracy or Ambivalent Bystander?" The Washington Diplomat (3 November 2013); available at https://www.washdiplomat.com/index.php? option=com_content\&view=article\&id=9726:obama-defender-of-democracy-or-ambivalentbystander\&catid=1510: november-2013\&Itemid $=428$.

92 Thomas Carothers, Democracy Policy Under Obama: Revitalization or Retreat? (Washington, D.C.: Carnegie Endowment for International Peace, 2012), 31-34; available at http://carnegieendowment.org/files/democracy_under_obama.pdf.

93 Marc Lynch, "Obama Recognizes Need to Embrace Democratic Change in Arab World," U.S. News \& World Report (27 September 2012); available at www.usnews.com/debate-club/hasobama-properly-handled-the-arab-spring/obama-recognizes-need-to-embrace-democraticchange-in-arab-world.

94 Phillip Saunders and Katrina Fung, "Wheels Up! Has Obama Really Pivoted to Asia?" The Diplomat (23 July 2013); available at http://thediplomat.com/2013/07/wheels-up-has-obamareally-pivoted-to-asia/.

95 Yoel Guzansky and Miriam Goldman, “America Can't Abandon the Middle East," The National Interest (18 March 2013); available at http://nationalinterest.org/commentary/americacant-abandon-the-middle-east-8232.

96 Ibid. 


\section{Advocates of Cold War}

For democratization to become the official policy of the United States rather than a pivot to the Asia-Pacific, the administration will have to contend with the Department of Defense's advocates of "AirSea Battle." These advocates are uniformed proponents of the military-industrial complex, who seek a Cold War-style enemy in order to justify continued high levels of defense spending. ${ }^{97}$ AirSea Battle, presently under development, is an operational concept that seeks to ensure the military's access into contested theaters of operation. ${ }^{98}$ AirSea Battle is spearheaded by the Navy and strongly supported by the Air Force. ${ }^{99}$ Unsurprisingly, these two services stand to lose the smallest share of the defense budget under the current scheme of reductions if the U.S. completes this pivot. ${ }^{100}$

The Navy and Air Force have had previous success in Pentagon budget politics. The Navy has been able to retain a large portion of defense spending over the past decade despite its lack of utility during combat operations in Iraq and Afghanistan. According to a recent RAND report, Army personnel have contributed 54 percent of the man-years spent by U.S. military personnel in Iraq and Afghanistan, while the Navy has accounted for 17 percent. ${ }^{101}$ A study in 2008 showed that the Army suffered 73.2 percent of the combat deaths in these conflicts, while the Navy suffered 2.2 percent. ${ }^{102}$ The Navy's most noteworthy achievement in the war against terror, the killing of Osama Bin Laden, was performed by a special operations organization that is well-suited for operations on land. Yet despite the disproportionate contributions ground forces have made in deposing the Hussein regime, enabling free Iraqi elections, and reducing Iraqi violence in later years, the Army in 2012 received only 31.2 percent of the total defense budget, while the Navy received 26.7 percent. ${ }^{103}$ Furthermore, the U.S. Navy enjoys a tremendous

97 Barnett, “AirSea Battle: The Military-Industrial Complex’s Self-Serving Fantasy."

98 See Amitai Etzioni, "Air-Sea Battle: A Dangerous Way to Deal with China," The Diplomat (3 September 2013); available at http://thediplomat.com/2013/09/air-sea-battle-a-dangerousway-to-deal-with-china/. See also William Yale, "Air-Sea Battle: A Dangerous, Unaffordable Threat," The Diplomat (9 November 2013); available at http://thediplomat.com/2013/11/airsea-battle-a-dangerous-unaffordable-threat/.

99 Representative J. Randy Forbes, “America's Pacific Air-Sea Battle Vision,” The Diplomat (8 March 2012); available at http://thediplomat.com/2012/03/americas-pacific-air-sea-battlevision/.

100 Barnett, “AirSea Battle: The Military-Industrial Complex’s Self-Serving Fantasy."

101 Dave Baiocchi, Measuring Army Deployments to Iraq and Afghanistan (Santa Monica, CA: RAND Corporation, 2013), 2.

102 Rod Powers, "The Cost of War," USMilitary.com (7 September 2008); available at http://usmilitary.about.com/od/terrorism/a/iraqdeath1000.htm.

103 U.S. Department of Defense, Office of the Under Secretary of Defense (Comptroller)/Chief Financial Officer, "Fiscal Year 2013 Budget Request" (February 2012), 8-3. 
overmatch at sea against any adversaries who are daring enough to challenge it. ${ }^{104}$ The Air Force has notably favored its jet fighter programs over drone aircraft. ${ }^{105}$

Have U.S. tax dollars been spent in the most efficient manner by sustaining dominance of the sea and air while allowing its ground forces to remain contested in a much more competitive environment? Are these the right proportions of service budgets for its national defense and security strategies? A grand strategy of democratization would imply that the U.S. must increase the proportion of the budget dedicated to its ground forces. The Army and Marine Corps, having learned much in the last decade about how to make the ground in the Middle East less fertile for terrorism, will have to continue to overcome institutional resistances towards low-intensity conflict in order to build more units that are better able to perform counterinsurgency missions in support of whole-ofgovernment nation-building efforts, at the expense of high-intensity missions like conventional warfare. ${ }^{106}$ If the present administration is to align its national security strategy correctly, it will have to resolve these discrepancies within the Department of Defense.

If the United States wants to reduce the chances of a terrorist attacking its domestic territory with a weapon of mass destruction, it must prioritize its efforts to enable the spread of democracy in the Middle East and Africa rather than pivoting to the Asia-Pacific. Hostile as some nations in East Asia might be, and as many territorial tensions as there are, threats in the region do not effectively threaten U.S. vital interests. The true nightmare for the United States is a nuclear bomb detonating in one of its great cities. Diverting resources away from this threat is effort misspent.

104 Robert Farley, "The False Decline of the U.S. Navy," The American Prospect (23 October 2007); available at http://prospect.org/article/false-decline-us-navy.

105 Spencer Ackerman, "Gates to Air Force: Get Used to Drones, Cargo Runs," Wired (4 March 2011); available at http://www.wired.com/dangerroom/2011/03/gates-to-air-force-get-usedto-drones-cargo-runs/.

106 William Rigby, "Nation Building: An Essential Army Task," U.S. Army War College Strategy Research Project (7 April 2003), 19. 


\section{Bibliography}

Abdallah, Abdel Mahdi. "Causes of Anti-Americanism in the Arab World: A SocioPolitical Perspective." Middle East Review of International Affairs 7, no. 4 (2003): 62-73.

Ackerman, Spencer. Gates to Air Force: Get Used to Drones, Cargo Runs. Wired, 2011.

Allison, Graham. Nuclear Terrorism: The Ultimate Preventable Catastrophe. New York: Times Books, 2004.

Archibugi, Daniele. "Cosmopolitan Democracy and its Critics: A Review." European Journal of International Relations 10 (2004): 437-473.

Bacevich, Andrew J.. "The Realist Persuasion." The Boston Globe (2005).

Baiocchi, Dave. Measuring Army Deployments to Iraq and Afghanistan. Santa Monica, CA: RAND Corporation, 2013.

Barnett, Thomas P. M.. "AirSea Battle: The Military-Industrial Complex’s Self-Serving Fantasy." Time (2012).

Boot, Max. "A Hard-Won Account of a Hard-Won Victory." The Wall Street Journal (2012).

Boyer, Dave. "Bush Policies Still Alive in Obama White House." The Washington Times (2013).

Bush, George W.. Freedom and Democracy in the Middle East In Address at the 20th Anniversary of the National Endowment for Democracy. Washington, D.C., 2003.

Bush, George W.. Update in the War on Terror In President's Address to the Nation., 2003.

Carothers, Thomas. Democracy Policy Under Obama: Revitalization or Retreat?. Washington, D.C.: Carnegie Endowment for International Peace, 2012.

Crenshaw, Martha. "The Causes of Terrorism." Comparative Politics 13, no. 4 (1981): 383-84.

Darwish, Nonie. Why Muslims Must Hate Jews. The American Thinker, 2012.

Elwell, Craig K., Marc Labonte, and Wayne M. Morrison. Is China a Threat to the U.S. Economy?. Washington, D.C.: Congressional Research Service, 2007.

Etzioni, Amitai. Air-Sea Battle: A Dangerous Way to Deal with China. The Diplomat, 2013.

Farley, Robert. The False Decline of the U.S. Navy. The American Prospect, 2007. 
Feaver, Peter. "Obama's Embrace of the Bush Doctrine and the Meaning of 'Imminence'." Foreign Policy (2013).

Fiscal Year 2013 Budget Request. U.S. Department of Defense, Office of the Under Secretary of Defense (Comptroller)/Chief Financial Officer, 2012.

Frantz, Douglas, and Catherine Collins. The Nuclear Jihadist: The True Story of the Man Who Sold the World's Most Dangerous Secrets and How We Could Have Stopped Him. New York: Twelve Hachette Group, 2007.

Freedberg, Jr., Sydney J.. China's Fear of US May Tempt Them To Preempt: Sinologists. Breaking Defense, 2013.

Fukuyama, Francis. "The Neoconservative Moment." The National Interest (2004).

Garrison, James. America as Empire: Global Leader or Rogue Power?. San Francisco: Berrett-Koehler, 2003.

Gordon, Michael R., and Bernard E. Trainor. The Endgame. New York: Pantheon, 2012.

Greene, Robert, and Jost Elfers. The 48 Laws of Power. London: Profile Books, 2000.

Guzansky, Yoel, and Miriam Goldman. America Can't Abandon the Middle East. The National Interest.

Harris, Sam. "Who Are the Moderate Muslims?" The Huffington Post (2006).

Hauser, Rita, Graham Allison, Dimitri Simes, and James Thompson. America's National Interests In The Commission on America's National Interests. Cambridge, MA: Belfer Center for Science and International Affairs, 2000.

Hipple, Matthew. 99 Red Balloons: How War With China Would Start. War on the Rocks, 2013.

Huntington, Samuel. The Clash of Civilizations and the Remaking of World Order. New York: Simon and Shuster, 1996.

J. Forbes, Randy. America's Pacific Air-Sea Battle Vision. The Diplomat.

J. Rochester, Martin. U.S. Foreign Policy: Kicking the Can Down the Road. St. Louis Jewish Light, 2013.

Kaplan, Robert. "The South China Sea Is the Future of Conflict." Foreign Policy (2011).

Kelly, Robert. Why the West Should Relax About China. The Diplomat, 2013.

Krauthammer, Charles. "In Defense of Democratic Realism." The National Interest (2004): 15-25. 
Leeson, Peter T., and Andrea M. Dean. "The Democratic Domino Theory: An Empirical Investigation (2009)." American Journal of Political Science 5, no. 3 (2009): 533-551.

Li, Quan. "Does Democracy Promote or Reduce Transnational Terrorist Incidents?" Journal of Conflict Resolution (2005): 278-297.

Lozowick, Yaacov. Right to Exist: A Moral Defense of Israel's Wars. New York: Random House, 2003.

Lynch, Marc. Obama Recognizes Need to Embrace Democratic Change in Arab World. U.S. News \& World Report, 2012.

Majumdar, Shuvaloy. The Iraq War and the Arab Spring. Global Brief, 2011.

McCarthy, Andrew C.. Re: American Conservatives, Islam, and Religious Realism in U.S. Foreign Policy. The National Review, 2013.

Moore, James W.. "Nuclear Terrorism: Exaggerating the Threat?" The Journal of Conflict Studies 26, no. 1 (2006): 121-142.

Morrison, Wayne M., and Marc Labonte. China's Holdings of U.S. Securities: Implications for the U.S. Economy. Washington, D.C.: Congressional Research Service, 2013.

Noer, John H., and David Gregory. Maritime Economic Interests \& the Sea Lines of Communication through the South China Sea: The Value of Trade in Southeast Asia. U.S. Center for Naval Analyses, 1996.

Nye, Joseph S. The Future of Power. New York: PublicAffairs, 2011.

Nye, Jr., Joseph S. "The China Threat." Foreign Policy (2011).

O'Rourke, Ronald. China Naval Modernization: Implications for U.S. Navy Capabilities - Background and Issues for Congress. Washington, D.C.: Congressional Research Service, 2013.

Oliver, Mark. "Palestinian TV uses Mickey Mouse to Promote Resistance." The Guardian (2007).

Ott, Marvin C. The Imperative for an American Strategy for Southeast Asia. Foreign Policy Research Institute, September, 2013.

Powers, Rod. The Cost of War. USMilitary.com, 2008.

Preble, Christopher A. The Trouble with Democracy in the Middle East. CATO Institute, 2003.

Rigby, William. Nation Building: An Essential Army Task In U.S. Army War College Strategy Research Project., 2003. 
Saunders, Phillip, and Katrina Fung. Wheels Up! Has Obama Really Pivoted to Asia?. The Diplomat, 2013.

Seminara, Dave. Obama: Defender of Democracy or Ambivalent Bystander?. The Washington Diplomat, 2013.

Skidmore, David. Contested Social Orders and International Politics. Nashville, TN: Vanderbilt University Press, 1997.

Stepan, Alfred, and Juan J. Linz. "Democratization Theory and the Arab Spring." Journal of De-mocracy 24, no. 2 (2013): 29.

Storey, Ian. "Asia's Changing Balance of Military Power: Implications for the South China Sea Dispute." In Maritime Energy Resources in Asia: Energy and Geopolitics. Seattle, WA: National Bureau of Asian Research.

Sustaining U.S. Global Leadership: Priorities for 21st Century Defense. Washington, D.C.: U.S. Department of Defense, 2012.

The National Security Strategy of the United States of America., 2002.

Toameh, Khaled Abu. Palestinians: We Hate You, So Please Pay Us More. Gatestone Institute, 2013.

Walt, Stephen M. "Beyond Bin Laden." International Security 26, no. 3 (2002): 56-78.

Wang, Kent. A Peace Agreement Between China and Taiwan. The Diplomat, 2013.

White, Hugh. The China Choice: Why We Should Share Power. Oxford: Oxford University Press, 2013.

Yemma, John. The China Paradox: Communist Capitalism?. The Christian Science Monitor, 2011. 